\title{
An optimized protocol for mouse bone marrow mesenchymal stromal cells isolation and culture
}

\author{
Dima Joujeh ${ }^{1}$, Abduljalil Ghrewaty ${ }^{1}$, Chadi Soukkarieh ${ }^{2}$, Adnan Almarrawi ${ }^{1}$, Jamal Abdul Naser Darwicha ${ }^{3}$ \\ ${ }^{1}$ Department of Biotechnology Engineering, Faculty of Technical Engineering, University of Aleppo, Syria \\ ${ }^{2}$ Department of Animal Biology, Faculty of Sciences, Damascus University, Syria \\ ${ }^{3}$ Department of Pharmacology and Toxicology, Faculty of Pharmacy, Arab International University, Syria.
}

Dr. Dima Joujeh, Department of Biotechnology Engineering, E-mail: dimajoujeh@gmail.com

Faculty of Technical Engineering, University of Aleppo,

Syria

Citation: Joujeh D, Ghrewaty A, Soukkarieh C, et al. An optimized protocol for mouse bone marrow mesenchymal stromal cells isolation and culture. Cell Ther Transplant 2021; 10(3-4): 61-70.

\section{Summary}

Mesenchymal stromal cells (MSCs) have stimulated much interest in the scientific community. Mouse MSCs serve as an ideal tool to explore cell biology and therapeutic potential of MSCs. Therefore, establishment of optimal, standardized protocol for mouse MSCs isolation and culture is required. Our aim was to develop and describe an efficient, reliable, and easy-to-perform protocol for isolation and culture of mouse bone marrow mesenchymal stromal cells MSC(M). Our protocol is based on a combination of flushing method and mechanical crushing of the bones. MSC(M) isolated using our protocol showed spindle-shaped appearance, positive expression of CD73 and CD44 markers, weak expression of CD34 and CD105, and negative expression for CD11b. They were also able to differentiate into mesodermal lineages such as adipocytes, and osteocytes. We hope that the data presented in this paper are of practical importance and can be used in clinical and research applications, and cell banking.

\section{Keywords}

$\mathrm{Balb} / \mathrm{c}$ mice, bone marrow cells, isolation, mesenchymal stem cells, primary culture.

\section{Introduction}

Bone marrow (BM) stroma is a complex tissue containing several cell types which provide a microenvironment for hematopoiesis and contribute to the maintenance and regeneration of skeletal tissues [1]. Two major stem cell populations with distinct progenies are found within adult BM, i.e., hematopoietic stem cells and mesenchymal stem cells (MSCs) [2]. MSCs were first described by Friedenstein et al. Who found that MSCs can be isolated by physical adhere to culture plates, able to form colonies with cells have fibroblast shape in vitro [3]. MSCs have also been defined as colony-forming fibroblastic cells, marrow stromal stem cells, mesenchymal progenitor cells [4], and, even, medicinal signaling cells [5].
MSCs are of interest in clinical applications for their ability to modulate the immune system, as well as their potential to regenerate tissues [6]. Medical applications of MSC require in vitro expansion in order to obtain sufficient cell numbers to achieve therapeutic results. Therefore, determination of optimal culture conditions is a prerequisite for usage of MSC in clinical setting [7].

However, prior to clinical implementation, the animal models are needed to confirm their efficacy and safety [8]. MSCs from mouse bone marrow (BM) provide valuable information on cell biology, potential function [9] and biochemical characteristics of MSC populations [8]. Human and rat bone marrow mesenchymal stem cells have been the most extensively characterized, due to relatively easy isolation procedure, their adherence to plastic dishes, and extensive in vitro expansion [10]. 
Isolation and purification of BM-MSCs from mouse are more difficult than from other species [9]. This observation is due to low frequency of BM-MSCs [11] and high proportion of hematopoietic stem cells (HSCs) in bone marrow [9]. The stromal cells exist near the surface of the bone, thus making it difficult to obtain enough MSCs, even after flushing BM by the cell preparation [8]. In addition, lack of specific mouse BM-MSC markers increases the difficulties [9].

To date, several suggestions were presented to improve the method of mouse BM-MSCs isolation, propagation, and culture, but none of them are widely acceptable [12]. We have reviewed most of the available protocols published so far, and attempted to develop an optimized, efficient, uncomplicated protocol suitable for production of a large number of MSC(M) in less than a week, thus enabling their use in regenerative medicine.

In this paper, we describe our MSC(M) isolation protocol in details, with appropriate illustrations, and index of some technical problems that occur when isolating and culturing MSCs, as well as expected causes of culture failures, and appropriate troubleshooting measures.

\section{Materials and methods}

\section{Experimental Animals}

Healthy mice (Balb/c, 4-6 weeks) were used in this study. Mice were housed in clean cages containing woodchip bedding, under a controlled temperature $(24 \pm 2)$ and light (12h light/ dark cycle) conditions, with free access to food and water. All procedures were performed according to the Guide for the Care and Use of Laboratory Animals and the ethical standards of our institution [13].

\section{Reagents and materials}

Dulbecco's modified Eagle's medium (DMEM), fetal bovine serum (FBS), L- glutamine, penicillin/streptomycin, amphotericin B, trypsin-EDTA (Euroclone, Italy), TRIzol Reagent (Sigma-Aldrich, USA), reverse transcriptase kit (Promega, USA), ladder (GeneDireX, Taiwan), Ethidium Bromide (Carl Roth, Germany).

\section{Isolation and culture of mouse MSC(M)}

1. To isolate marrow, the mouse is sacrificed by cervical dislocation. Then, the mouse is brought to a laminar hood.

2. Place the animal in dorsal position on the dissecting board and thoroughly spray the animal skin with $70 \%$ ethanol to prevent contamination from the skin.

3. Incise the skin around the perimeter of the hindlimbs, pull the skin down toward the foot, and cut at the anklebone along with the peeled skin. Then, disconnect the hind limbs from the trunk (Fig. 1).

4. Remove the muscles, ligaments, and tendons attached to the bones carefully using sterile surgical scissors, forceps and scalpel.

5. Separate tibias and femurs by bending them in opposite direction and cutting through the knee joint, ensuring that the epiphysis remains intact.
6. Transfer the bones to pre-warmed DMEM medium $\left(37^{\circ} \mathrm{C}\right)$ in a sterile Petri dish to preserve viability.

7. Cut the epiphyses of the tibia and femur carefully just below the end of the marrow cavity using sterile, sharp scissors.

8. Insert a 27 -gauge needle attached to a 1-ml insulin syringe filled with complete DMEM medium heated to $37^{\circ} \mathrm{C}$, supplemented with $1 \%$ L-glutamine, $1 \%$ penicillin-streptomycin $(\mathrm{P} / \mathrm{S})$, and $1.5 \mu \mathrm{g} / \mathrm{ml}$ amphotericin B into the bone cavity and flush the marrow out of the cut end of the bone into a $15 \mathrm{ml}$ Falcon tube. In order to obtain enough marrow cells, repeat this process from both ends of the bone (use $1.4 \mathrm{ml}$ of DMEM for each bone). Add 10\% FBS to the bone marrow suspension and gently mix it with a pipette. Transfer the suspension to a cell culture flask. Incubate this flask in an incubator at $37^{\circ} \mathrm{C}$ in a humidified atmosphere containing $5 \%$ $\mathrm{CO}_{2}$.

9. After flushing out the marrow, transfer the bones to a mortar containing $5 \mathrm{ml}$ of complete DMEM medium, and crush bones gently with pestle using only enough force to crack open the bones and extract the remainder of the bone marrow. Mix gently and transfer the cell suspension to a plastic culture flask. Incubate the flask in an incubator at $37^{\circ} \mathrm{C}$ and $5 \% \mathrm{CO}_{2}$.

10. Determine yield and viability of the isolated cells using a hemocytometer/automated cell counter and Trypan Blue staining.

11. After $24 \mathrm{~h}$ at $37^{\circ} \mathrm{C}$, replace the culture medium to remove non-adherent cells and tissue debris with $5 \mathrm{~mL}$ of complete DMEM medium (20\% FBS). Later on, replace the culture medium daily.

12. On the 5th day, remove the culture medium and wash the cells with phosphate buffer saline (PBS 1X), then detach the adherent cells by adding $1-1.5 \mathrm{ml}$ of $0.25 \%$ trypsin into the flask for $2 \mathrm{~min}$ at $37^{\circ} \mathrm{C}$. Neutralize trypsin by adding $3 \mathrm{ml}$ of DMEM medium (20\% FBS). Transfer the cell suspension into a $15 \mathrm{ml}$ Falcon tube, and centrifuge for 3-5 $\mathrm{min}$ at 1000 $\mathrm{rpm}$. Passage the resulting cells at a split ratio of $1: 2$ or 1:3.

\section{Gene expression assay for molecular phenotyping}

Total RNA was isolated from MSC(M) using TRIzol Reagent. The quantity and quality of the isolated RNA were evaluated by Thermo Scientific NanoDrop 2000. RNA was reversely transcribed into complementary DNA (cDNA) from $1 \mu \mathrm{g}$ of total RNA in a $20 \mu \mathrm{l}$ reaction mixture by means of reverse transcriptase kit (Promega, USA), according to the manufacturer's instruction. PCR of the cDNA samples was applied to detect expression of CD73, CD44, CD105, CD11b, CD34, with GAPDH gene used as a reference. To check expression of each gene, $4 \mu \mathrm{l}$ of $\mathrm{cDNA}$ was added to the gene-specific primers in $25 \mu$ total reaction mixture. Primer sequences for GAPDH and CD34 genes were obtained from the published reports $[14,15]$, whereas primers for CD11b, CD73, CD44, CD105 genes were designed using NCBI database. Table 1 summarizes gene names, forward and reverse primer sequences, annealing temperatures and expected amplicon length. The PCR conditions were as follows: (1) 10 minutes at $95^{\circ} \mathrm{C}$, (2) 35 cycles of 30 seconds at $95^{\circ} \mathrm{C}, 45$ seconds at 


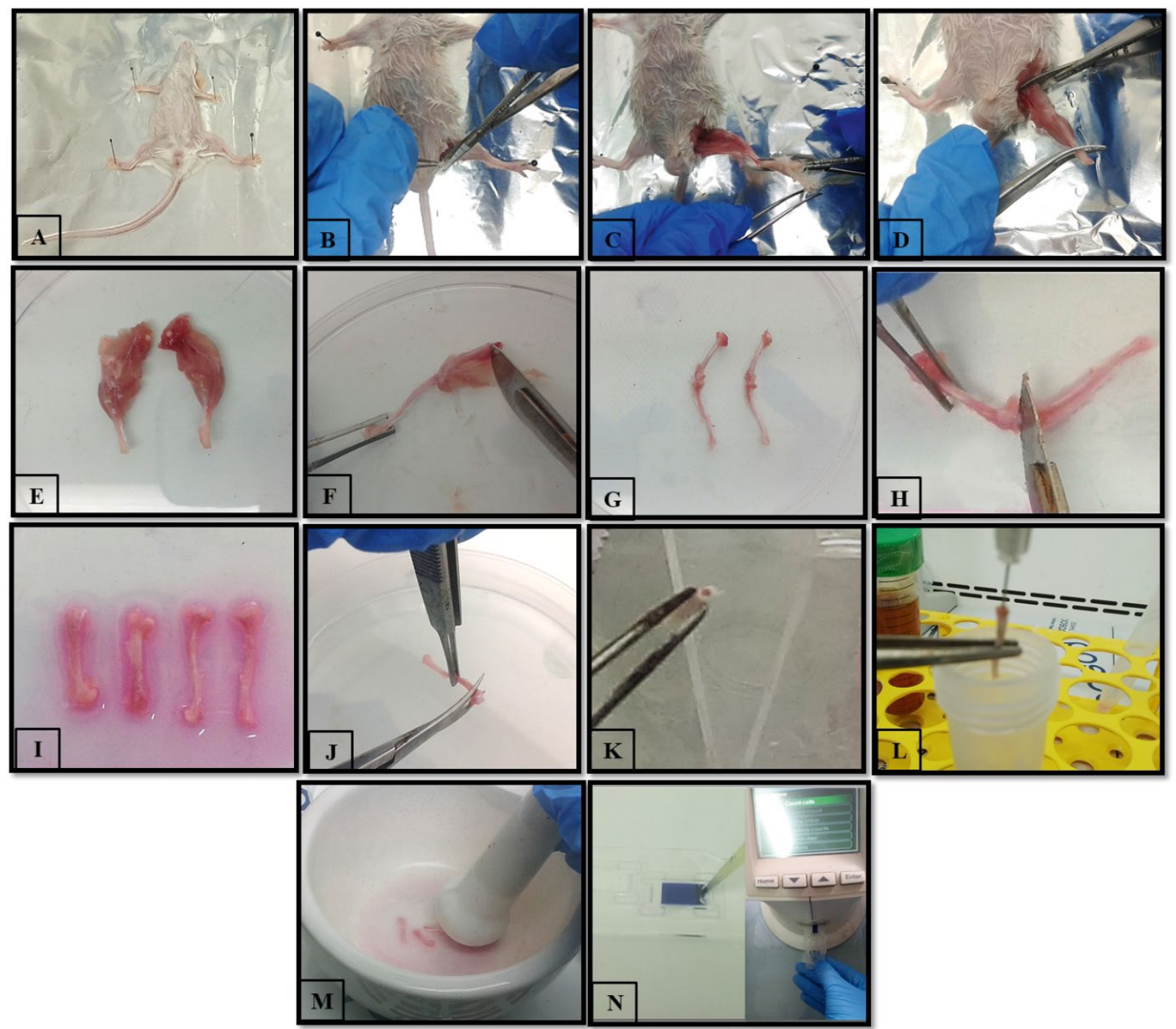

Figure 1. Stepwise procedure of mesenchymal stromal cells isolation from the bone marrow of Balb/c mice

The mouse was sacrificed by a cervical dislocation, and the animal skin is sprayed with $70 \%$ ethanol (A). Skin was incised around the perimeter of the hind limbs (B). The foot with peeled skin was cut at the anklebone (C). Hind limbs were disconnected from the trunk, and transferred to a sterile Petri dish (D, E). Muscles, ligaments, and tendons were removed from the bones (F). Bones cleared from the rest of muscles $(\mathrm{G})$. Tibias and femurs were separated by cutting through the knee joint $(\mathrm{H})$, and transferred to pre-warmed DMEM medium in a sterile Petri dish (I). Epiphyses were cut using sterile, sharp scissors (J). Bone marrow was flushed out of the bone $(\mathrm{K}, \mathrm{L})$. Bones were crushed gently to extract the remainder of the bone marrow $(\mathrm{M})$. Yield and viability of cells was determined using automated cell counter $(\mathrm{N})$.

Table 1. Genes assayed, NCBI accession number, forward and reverse primer sequences, annealing temperatures and amplicon sizes for PCR analysis

\begin{tabular}{|l|l|l|l|l|}
\hline Gene & Accession number & Primer sequence (5' $\left.{ }^{\prime}>3^{\prime}\right)$ & Annealing temperature, ${ }^{\circ}$ C & Product length (bp) \\
\hline CD34 & NM_133654.3 & $\begin{array}{l}\text { F: 5- CCTACCAATGAGTCTGTTGAGG-3 } \\
\text { R: 5- GAAGTAGTAGGCAGTATGCCAG-3 }\end{array}$ & 53 & 215 \\
\hline CD11b & NM_008401.2 & $\begin{array}{l}\text { F: 5- GGCAACCATGGAATTCAGCC -3 } \\
\text { R: 5- GAGCGGCCAGGGTCTAAAGC -3 }\end{array}$ & 55.1 & 192 \\
\hline CD73 & NM_011851.4 & $\begin{array}{l}\text { F: 5- ACGTGCTGTTTTGGATGCC -3 } \\
\text { R: 5- AGTGCCATAGCATCGTAGCC -3 }\end{array}$ & 54.9 & 115 \\
\hline CD105 & NM_001146350.1 & $\begin{array}{l}\text { F: 5- GAAGCAAGGTCAAAGGCGTG -3 } \\
\text { R: 5- GTCTTCAGCCTGGCAGC -3 }\end{array}$ & 54 & 344 \\
\hline CD44 & NM_009851.2 & $\begin{array}{l}\text { F: 5- CGCACAGAAGACAACCAGGA -3 } \\
\text { R: 5- CCGGGGTCCATTTTCTCCA -3 }\end{array}$ & 55.1 & 136 \\
\hline GAPDH & NM_001289726.1 & $\begin{array}{l}\text { F: 5- GAGAAACCTGCCAAGTATG-3 } \\
\text { R: 5- GGAGTTGCTGTTGAAGTC-3 }\end{array}$ & 48.3 & 123 \\
\hline
\end{tabular}



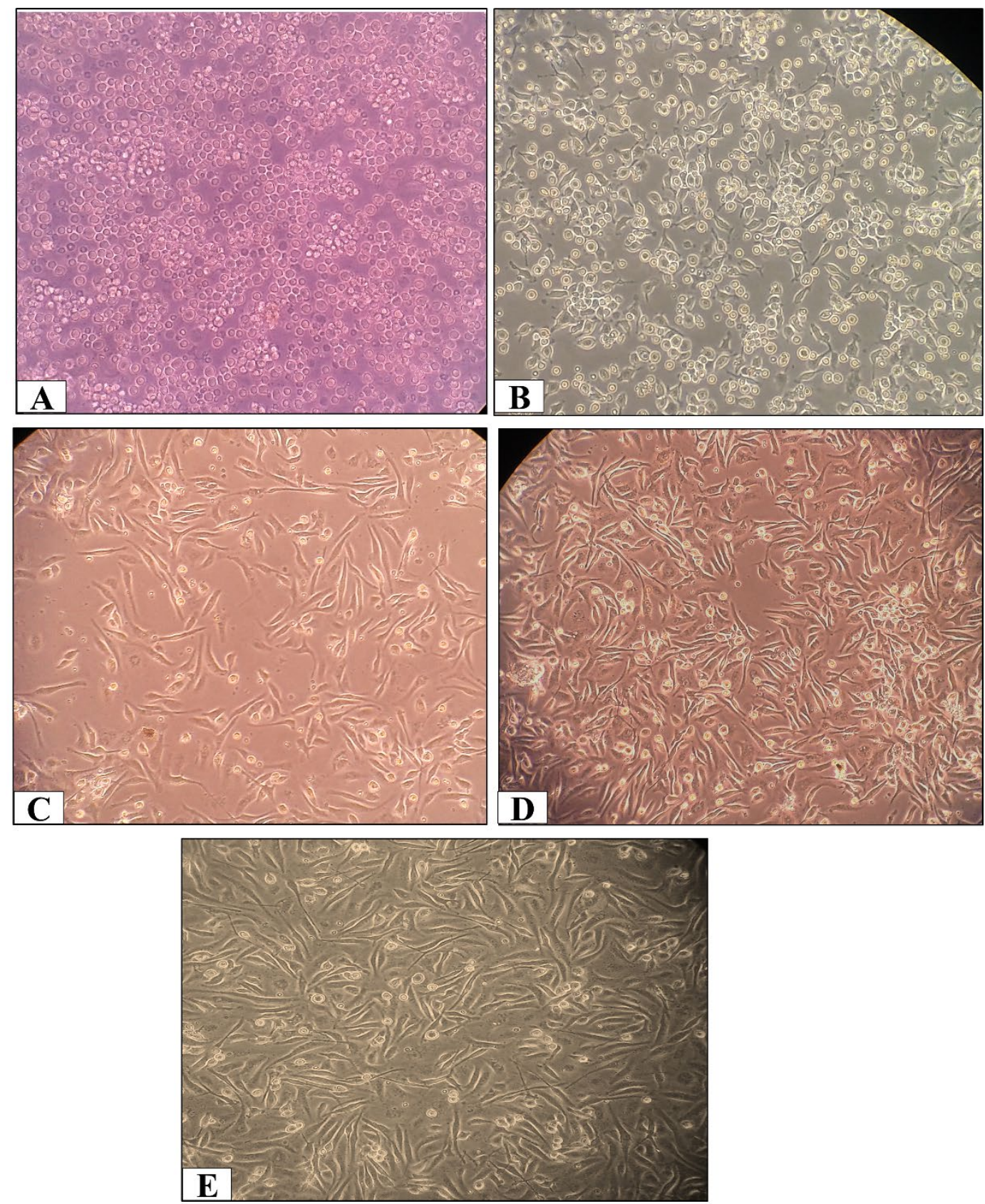

\section{Figure 2. Morphological features of cultured mouse MSC(M) at passage 0}

(A) Rounded-shape cells settled down within 10 minutes of seeding. (B) Following 24 hours of cultivation, some spindle-shaped cells appeared. (C) The ratio of spindle-shaped cells increased on Day 3. (D) On Day 4, the spindle-shaped cells reached about $60-70 \%$ confluence. (E) On Day 5 of culture, the cells reached $80-90 \%$ confluence, being passaged at this term.

primer annealing temperature, and 45 seconds at $72^{\circ} \mathrm{C}$, (3) 10 minutes at $72^{\circ} \mathrm{C}$. Following PCR, the amplicons were detected on $2 \%$ agarose gel using a 50 bp ladder (GeneDireX, Taiwan) and Ethidium Bromide to visualize the amplicons.

\section{Adipogenic Differentiation}

Adipogenic differentiation ability was evaluated in vitro, according to [16], with slight modifications. The cells were plated in 96-well plate in complete DMEM medium (10\% FBS). After 24 hours, the medium was replaced by adipogenic induction medium (complete DMEM medium supplemented with $10 \% \mathrm{FBS}, 2 \mu \mathrm{M}$ dexamethasone, $0.1 \mathrm{mM}$ indomethacin, and $5 \mu \mathrm{g} / \mathrm{ml}$ insulin). Cells cultured in a complete DMEM medium (10\% FBS) were used as a negative control. After one week, the cells were fixed with 10\% Paraformaldehyde (PFA) for 20 min and stained with Sudan III (1\%) to detect the formation of lipid droplets, then washed with distilled water. Lipid droplets were detected by inverted microscope (Olympus IX53, Japan).

\section{Osteogenic differentiation}

Osteogenic differentiation ability was evaluated according to [17], with slight modifications. Cells were plated in 96 well plate in complete DMEM medium (10\% FBS). After 24 hours, the medium was replaced with osteogenic induction medium (complete DMEM medium supplemented with $10 \%$ FBS, $10 \mu \mathrm{M}$ dexamethasone, $10 \mathrm{mM} \beta$-glycerophosphate, and $50 \mu \mathrm{M}$ ascorbic acid). Cells cultured in a complete 
DMEM medium (10\% FBS) were used as a negative control. After 1 week, the cells were fixed with $10 \%$ Paraformaldehyde (PFA) for 20 min and stained with Alizarin Red (2\%) to detect the presence of calcium deposits, then washed with distilled water. Calcium deposits were detected by inverted microscope.

\section{Results}

\section{Morphology of isolated MSC(M) in culture}

MSC(M) were isolated from the femurs and tibias of Balb/c mouse according to their adherence to a culture flask. Using our protocol, we obtained $\sim 75-90^{\star} 10^{6}$ of BM mononuclear cells (BMMNCs) with $94 \%$ viability using flushing process, and $\sim 10-20^{\star} 10^{6}$ of BMMNCs with $84 \%$ viability by crushing process. Isolated MSC(M) settled down within 10 minutes of seeding and showed round-shaped morphology with various sizes. After 24 hours, the MSC(M) attached to the flask surface and non-adherent cells were carefully removed by medium changing. After 24 hours of cultivation, some cells became spindle. On Day 3, the number of spindle-shaped cells increased dramatically. On Day 4, the spindle-shaped cells reached about $60-70 \%$ confluence. On Day 5 , the cells grew and form $80-90 \%$ confluent monolayer (Fig. 2), and cells were passaged on this day.

\section{Characterization of cell surface markers}

In this study, MSC(M) isolated from Balb/c mouse were characterized to investigate expression of surface antigens, and the results indicated that the cells were positive for CD73, and CD44, since the bands appeared at the expected distances when PCR products were subjected to electrophoresis in $2 \%$ agarose gel. Moreover, there was no detectable CD11b expression, along with only weak expression of CD34 and CD105 (Fig. 3).

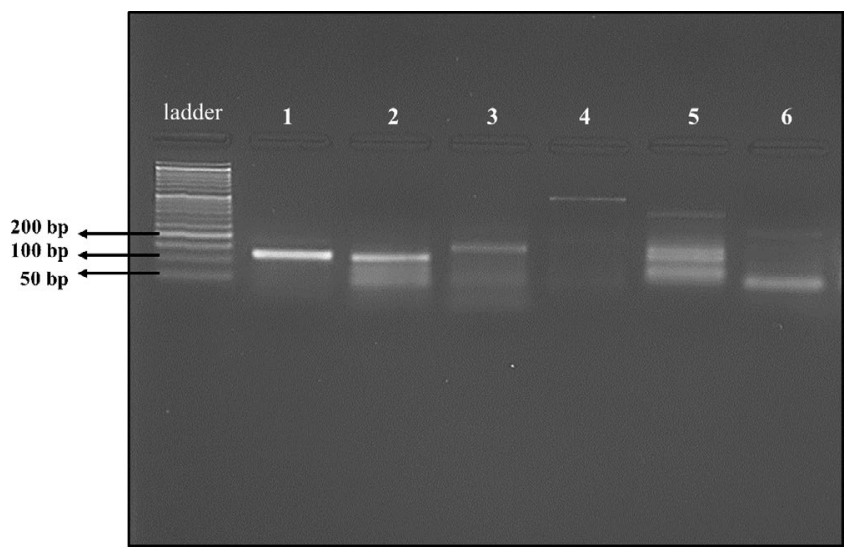

Figure 3. Expression of MSC gene markers detected by RT-PCR and agarose gel electrophoresis (lanes 1 to 6 ) for the following PCR products: (1) GAPDH (123bp) used as control; (2) CD73 (115 bp); (3) CD44 (136 bp); (4) CD11b (192 bp); (5) CD105 (344 bp); (6) CD34 (215 bp)

\section{Adipogenic and osteogenic differentiation:}

Adipogenic and osteogenic differentiation potential of isolated MSC(M) was tested. Following 7 days of culture under adipogenic induction conditions, MSC(M) showed marked morphological changes compared to the undifferentiated cells (control). They also showed accumulation of several cytoplasmic lipid droplets. After staining with lipophilic Sudan III, the control cells did not show any cytoplasmic changes and were negative for Sudan III staining, while distinct cytoplasmic lipid droplets were observed in MSC(M) grown in adipogenic medium (Fig. 4).

Following 7 days of culture in osteogenic induction medium, MSC(M) showed morphological changes and acquired

(A)

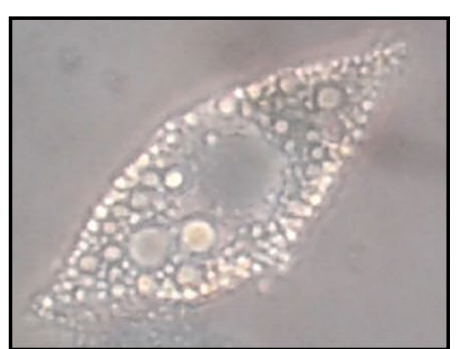

(a)

(B)

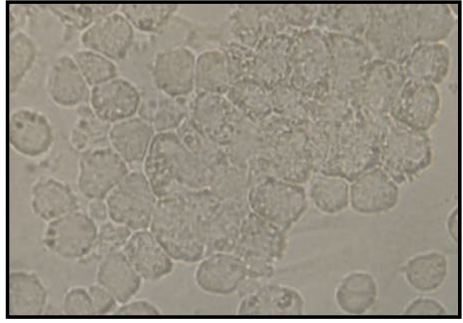

(a)

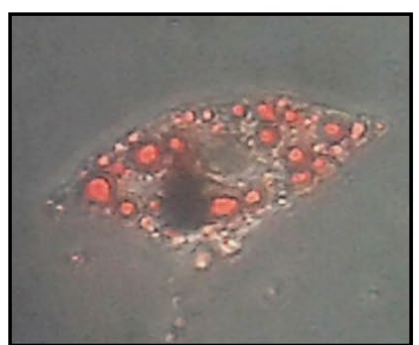

(b)

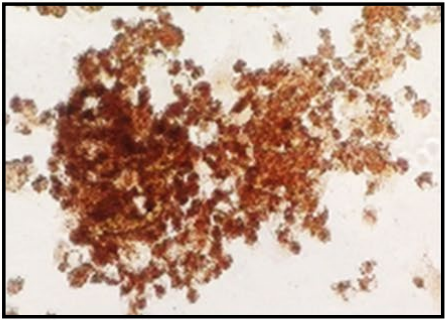

(b)

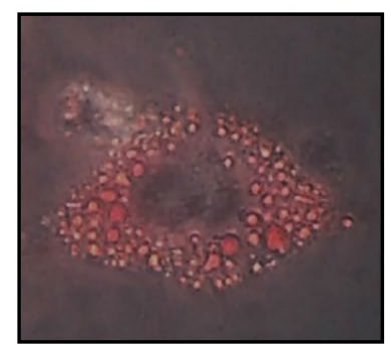

(c)

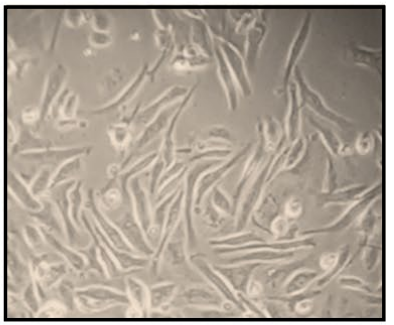

(c)

Figure 4. Mesodermal differentiation of $\operatorname{MSC}(M)$ at the passage 0

A: Adipogenic differentiation of MSCs: (a) BMSCs after induction with adipogenic medium, showing formation of intracytoplasmic lipid droplets; (b, c). Positive staining of lipid droplets with Sudan III. (B): Osteogenic differentiation: (a). BMSCs after induction with osteogenic medium showed cuboidal morphology (b). Alizarin Red staining indicated dark red precipitation of calcium deposits. (c) Control BMSCs cultured in DMEM medium (10\%FBS). 
cubical shape, whereas control cells did not show any morphological changes. After staining with Alizarin Red, the control cells were dye-negative, whereas differentiated cells were positively stained, indicating the presence of calcium deposits (Fig. 4).

\section{Discussion}

\section{Cell isolation procedure}

Mesenchymal stromal cells (MSCs) are used in many research fields and have sparked great interest in cell therapies due to their ability to differentiate into various cell types [18]. MSC culture was first established by Friedenstein and his colleagues by virtue of the physical propensity of MSCs to adhere to plastic flasks, and the original method has been modified by others [19]. Several methods have been used for isolating $\operatorname{MSC}(\mathrm{M})$ including whole marrow direct adherence, density gradient centrifugation, flow cytometry and immunobead methods. However, the latter two methods are considered high in cost and technically difficult [20]. The direct culture method is best to culture high number of MSC(M) within very short time and at high viability rate [21]. It is clearly easier and reduce loss of MSCs compared to density gradient separation approach. However, the cells collected by this method represent a heterogeneous mixture of cells, including hematopoietic cells, endothelial cells and endothelial progenitor cells [11]. This problem was solved using frequent medium change that may prevent adherence of many of the non-MSCs and hematopoietic cells to the culture dishes [2].

Usage of adult MSCs in human therapeutic applications depends on the establishing of preclinical studies with other mammals such as mouse [22]. In order for such therapies to be reproducibly performed in preclinical animal models, a simple, high-yield method for obtaining MSCs is required [19]. In this study, MSC(M) were isolated from the mice aged 4-6 weeks. We obtained high cellular yield, and the isolated cells were able to grow and proliferate within a short period of time. Previous study indicated that age of the animals used as MSCs source directly influences their differentiation, proliferative and metabolism profiles [23]. According to [19], younger mice (sucklings of $<3$ weeks) produce more proliferative cell cultures. Long bones of newborn mice (up to one week of age) are quite fragile, thus being inconvenient for researchers who have no relevant experience handling them.

- We found that a delay in isolation process from sacrificing the mouse to BM collection and culture, greatly affects the yield and viability of the isolated cells. This step is very critical and requires experience and accuracy during work.

- In this study, MSC(M) were isolated using an adherence method, the culture medium was replaced daily during the first four days of culture, in order to provide the cells with the nutrients required for their growth and proliferation. At the same time, the daily change of the culture media may prevent adherence of many non-MSCs, e.g., hematopoietic populations, to the culture dishes. According to our experience, we do not recommend replacement of the culture medium two or three hours after primary cell culture because we found that this process results in loss of some MSCs and thus obtaining a lower cellular yield.
- Two types of culture media (DMEM or RPMI 1640) supplemented with $20 \%$ FBS, $1 \%$ L-glutamine, $1 \%$ penicillin/ streptomycin and $1.5 \mu \mathrm{g} / \mathrm{ml}$ amphotericin B were used in our study in order to choose the optimal medium, and the results demonstrated that the both media are suitable for MSC(M) culture and proliferation, since no differences in cell viability, growth or proliferation were observed.

- Fetal bovine serum (FBS) seems to be the most popular choice of supplements in the culture media. It may play a key role in promoting cell attachment and proliferation [24]. In the current protocol, FBS concentration was increased to $20 \%$, and we found that this concentration was suitable for obtaining sufficient numbers of MSCs within a short period of time.

- After separating bones from the muscles, they were directly transferred to a Petri dish containing 3-4 $\mathrm{ml}$ of prewarmed DMEM medium $\left(37^{\circ} \mathrm{C}\right)$, without additives of serum or antibiotics, to preserve cell viability.

- To reduce the possibility of contamination, the bones should not be transferred to the culture media before cleaning it from the muscle.

- To reduce the possibility of contamination, a fresh media should be used to flush the marrow out of the bone rather than using the media in which the bones were placed after separating from the muscle.

- In this study, the marrow was flushed out from both ends of the bone to obtain a high cellular yield, as proposed by [25].

- Only $1.4 \mathrm{ml}$ of culture medium is sufficient for flushing the marrow out of the bone, then the bones could be transferred to a sterile mortar containing $5 \mathrm{ml}$ of culture medium, and gently crushed to extract the remaining bone marrow. We found that this step is very useful to obtain a high MSC(M) yield, because the stromal cells locate near the surface of the bone, which makes it difficult to obtain enough MSCs, even after flushing BM during cell preparation [8].

- In our study, after collecting the BM suspension, it was immediately transferred to the culture flask, without centrifugation or filtration. MSC(M) were cultured into their initial niche composing of stromal cells, extracellular matrix elements, and secreting factors with minimal disturbance, to allow the initial adjusting time for the MSCs in culture, according to [26]. We found this method to be more efficient. However, in our protocol, the culture medium was replaced daily, contrary to what was suggested by [26] who kept the cells in their niche for 4 days without replacing the media.

- Using our modified protocol, we were able to isolate 25\% more BMMNCs than the commonly used protocol.

- On the fifth day of culture, MSC(M) reached about 80$90 \%$ confluence. Hence, they were passaged to prevent overgrowth and cell detachment. MSC(M) are strongly attached to the flask and can't be easily detached from the flask using trypsin solution at lower concentration $(0.05 \%)$. Therefore, a more concentrated trypsin solution $(0.25 \%)$ was used to detach the cells. 
- The trypsinization conditions should be carefully controlled. It is necessary to adhere to the concentration of the trypsin solution used to separate the cells, as well as incubation time. Insufficient trypsin treatment will reduce the yield of cells [11]. On the other hand, bone marrow-derived adherent cells were found to contain different cell types including fibroblasts, hematopoietic progenitor cells, macrophages, endothelial cells and adipocytes [4]. Longterm incubation with trypsin resulting in collection of other unwanted trypsin-resistant cells, e.g., macrophages [19], which firmly adhere to cell culture dishes, whereas MSCs were shown to be more responsive to trypsin [4]. Excessive trypsinisation may also damage cells by striping cell surface proteins. The most prominent problems that researchers may face in the mouse MSC $(\mathrm{M})$ isolation and culture and possible solutions for them are listed in Table 2.

\section{Cell Surface Markers}

Mammalian bone marrow contains a myriad of stem cells with distinctive morphological and functional features such as mesenchymal stem cells (MSCs), hematopoietic stem cells (HSCs), multipotent adult progenitor cells (MAPCs) and very small embryonic-like stem cells (VSELs) [12]. Due to growing interest in using MSCs for cell-based therapy, the need to identify MSCs in a definitive way is not only of research interest but also derives from clinical requirements [27].

The isolation of distinct cell types from bone marrow stroma is hindered by the lack of known specific surface markers for those cells. To date, only a set of markers can identify stem/ stromal cells from bone marrow, and none of them is unique [1].

\section{Table 2. Some problems and suggested solutions for mouse MSC(M) isolation and culture}

\begin{tabular}{|c|c|c|}
\hline Problem & Possible cause & Solution \\
\hline $\begin{array}{l}\text { Low yield of harvested } \\
\text { cells }\end{array}$ & $\begin{array}{l}\text { - Age of the mouse. } \\
\text { - Bone marrow has not been } \\
\text { flushed well. } \\
\text { - The bone was broken, and cells } \\
\text { were lost }\end{array}$ & $\begin{array}{l}\text { - Isolate cells from mouse at 4-6 weeks of age. } \\
\text { - Use strong flushing to harvest the marrow, repeat the process from } \\
\text { both ends of the bones, transfer the bones to a mortar containing DMEM, } \\
\text { and crush gently to extract the remainder of BM. } \\
\text { - Use sharp-bladed scissors to cut the epiphysis to avoid breaking the } \\
\text { bone and cell losses. }\end{array}$ \\
\hline Low cell viability & $\begin{array}{l}\text { - The cells die due to prolonged } \\
\text { isolation process. }\end{array}$ & $\begin{array}{l}\text { - Perform all the steps of BM isolation (from sacrificing the mouse } \\
\text { to BM collection and culture) within short time period ( } \leq 10-15 \text { minutes) } \\
\text { to preserve good cell viability and high cellular yield. } \\
\text { - Immediately after bone cleaning, transfer it to a Petri dish with } \\
\text { pre-warmed DMEM }\left(37^{\circ} \mathrm{C}\right) \text {, to maintain cell viability. }\end{array}$ \\
\hline $\begin{array}{l}\text { Bacterial or fungal con- } \\
\text { tamination }\end{array}$ & $\begin{array}{l}\text { - Insufficient sterilization of the } \\
\text { dissection tools; contamination of } \\
\text { reagents used for the cell culture } \\
\text { (culture medium, serum, antibiot- } \\
\text { ics). } \\
\text { - Inappropriate laboratory prac- } \\
\text { tices. }\end{array}$ & $\begin{array}{l}\text { - Ensure sterility of the reagents used, good sterilization of the tools, and } \\
\text { perform all isolation and culture steps within aseptic hood. } \\
\text { - Spray animal skin with ethanol. } \\
\text { - Clear the bones well from muscular tissues before transferring them to } \\
\text { the DMEM-containing Petri dish. } \\
\text {-Strict adherence to good laboratory practices. }\end{array}$ \\
\hline $\begin{array}{l}\text { The number of adherent } \\
\text { cells is low after } 24 \text { hours } \\
\text { of culture }\end{array}$ & $\begin{array}{l}\text { - Microbial contamination. } \\
\text { - Lack of sufficient attachment } \\
\text { factors in the serum. } \\
\text { - Inappropriate culture conditions. }\end{array}$ & $\begin{array}{l}\text { - Check for microbial contamination. } \\
\text { - Check the quality of the serum used. Fetal blood serum (FBS) plays a } \\
\text { key role in promoting cell attachment and proliferation. Make sure that } \\
\text { the bovine serum used is fetal. } \\
\text { - Verify incubator conditions }\left(5 \%\left(\mathrm{C}_{2}, 37^{\circ} \mathrm{C}\right) \text {. }\right. \\
\text { - The flask should not be moved during the first hours of culture enabling } \\
\text { cell adherence to the surface of flasks. }\end{array}$ \\
\hline $\begin{array}{l}\text { Cells grow slowly in the } \\
\text { culture }\end{array}$ & $\begin{array}{l}\text { - Quality and concentration of fetal } \\
\text { bovine serum (FBS) used. } \\
\text { - Inappropriate culture conditions. }\end{array}$ & $\begin{array}{l}\text { - Increase FBS amount in cell culture to final } 20 \% \text { concentration. Ensure } \\
\text { fetal origin of the bovine serum. } \\
\text { - Keep the required limits of incubator regimen }\left(5 \% \mathrm{CO}_{2^{\prime}} 37^{\circ} \mathrm{C}\right) \text {. }\end{array}$ \\
\hline Excessive cell death & $\begin{array}{l}\text { - Culture medium is not replaced } \\
\text { after } 24 \text { hours of culture. }\end{array}$ & $\begin{array}{l}\text { - Using our protocol, it is necessary to replace the medium after } 24 \text {-h cul- } \\
\text { ture, the medium should be daily replaced over the first days of culture, } \\
\text { in order to remove non- adherent hematopoietic stem cells. } \\
\text { - Be sure that fetal bovine serum is heat-inactivated before using it. }\end{array}$ \\
\hline $\begin{array}{l}\text { Difficulty with detach- } \\
\text { ment of MSC(M) cells from } \\
\text { culture flasks }\end{array}$ & $\begin{array}{l}\text { - Low concentration of trypsin } \\
\text { enzyme used for digestion. } \\
\text { - Loss of the enzyme activity } \\
\text { - Residual FBS which inhibits tryp- } \\
\text { sin activity. }\end{array}$ & $\begin{array}{l}\text { - MSC(M) are strongly attached to the flask and can't be easily detached. } \\
\text { Use high concentration of trypsin (0.25\%) to detach cells. } \\
\text { - Pre-warm trypsin solution before use (optimal activity is achieved } \\
\left.\text { at } 37^{\circ} \mathrm{C}\right) \text {. } \\
\text { - Rinse well with PBS before adding trypsin. }\end{array}$ \\
\hline Cell death after passaging & $\begin{array}{l}\text { - Long-term incubation at high } \\
\text { trypsin concentration. }\end{array}$ & - Incubate with trypsin for only 2 minutes. \\
\hline
\end{tabular}


In this study, MSC(M) isolated from Balb/c mice were characterized to investigate gene expression of the surface markers, and the results indicated that the cells were positive for (CD73 and CD44), negative for (CD11b), while they showed weak expression of CD34 and CD105 (Fig. 3). These results demonstrated that the isolated cells were MSC-like in morphology, adhesion to plastic surfaces, expression of surface markers, and in adipogenic/osteogenetic differentiation potential. Although the isolated MSC(M) showed characteristics of mesenchymal stromal cells, we suggest that there is a low proportion of hematopoietic stem cells, since the cells were characterized at the passage ( $\mathrm{P} 0)$, and it has been reported that hematopoietic stem cells still exist in the culture even after nine in vitro passages [19]. Increased number of cell passages could result in a significant reduction of hematopoietic stem cells.

Mouse MSCs are generally characterized by positive expression of CD44, CD73, CD105, CD29, CD106, Sca-1, and negative expression of hematopoietic and endothelial markers CD45, CD11b, Ter-119, and CD31 [6]. Our results showed that the surface marker CD profiles for the MSC(M) were compatible with those previously reported.

It has been demonstrated that CD34 expression is not specific for murine hematopoietic cells, as it was shown for human cells. Previous study reported that the expression of CD34 was strain-dependent in mice. Bl/6 MSCs expressed high levels of CD34, with moderate expression by FVB/N MSCs. Both Balb/c and DBA1 MSCs expressed low levels, while MSCs from the 4 standard inbred strains were negative for CD11b [10].

\section{Adipogenic and osteogenic potentials}

MSCs are defined by their ability to differentiate and generate cells of mesodermal origin like adipocytes, osteocytes and chondrocytes in culture [6]. The results of mesodermal differentiation assays showed that isolated $\operatorname{MSC}(\mathrm{M})$ were able to differentiate into adipocytes and osteocytes in vitro. MSC(M) cultured in adipogenic medium showed morphological changes and displayed accumulation of lipid vacuoles, which stained positively with Sudan III. Lipid droplets in differentiated cells became red due to their affinity for lipophilic Sudan III dye. Similarly, MSC(M) cultured in osteogenic medium showed morphological changes and stained positively with Alizarin Red, indicating presence of calcium deposits. Our results are consistent with previous reports, and demonstrate the opportunity of using these cells in both clinical and research applications.

In the current study, MSC(M) at passage 0 were able to differentiate into adipocyte and osteoblasts like cells within only seven days of incubating with differentiation medium. Meanwhile, many previous studies indicated that adipogenic and osteogenic differentiation takes about three weeks. This slow dynamic may be due to the fact that cell differentiation capability and function decline with repeated passaging [28].

Previous research demonstrated that BMSCs from passage 3 were inferior to bone marrow mononuclear cells (BMMNCs) not only in their chondrogenic differentiation capability but also as candidates for long-term repair of cartilage defects [28]. Previous study reported that MSCs from passage 1 have stronger osteogenic potential in vitro than those of passages 2 and 3 , and might be suitable for clinical application to bone tissue engineering [29].

Differentiation of MSCs into various lineages is strictly regulated at multiple sequential steps, being represented by distinct morphological and molecular characteristics [12]. Until now, the mechanism of MSCs trans-differentiation is unclear. There are many internal and external factors that trigger MSCs differentiation.

\section{Conclusion}

Increased demand for MSCs in research and medical studies has led scientists to give priority to the development of standardized MSCs isolation and culture methods. In the present study, we have successfully isolated MSC(M) from $\mathrm{Balb} / \mathrm{c}$ mouse under optimized isolation and culture conditions. We have also listed the most prominent problems that researchers may face and suggested the possible solutions for them. We hope that this simple and practical method will facilitate the study of MSCs, both for examining their biological properties, as well as their therapeutic potential in various murine disease models.

\section{Acknowledgments}

The authors are grateful to the Leishmania Center of Epidemiological and Biological Studies, National Commission for Biotechnology (Department of Pharmaceutical Biotechnology). We would like to thank Dr. Ruba Joujeh, Dr. Hassan Alkhoury, Dr. Majd Aljamali, Dr. Fateh Khatib, Ms. Reham Antaki, for their help and support. This research was funded by the University of Aleppo.

\section{References}

1. Rostovskaya M, Anastassiadis K. Differential expression of surface markers in mouse bone marrow mesenchymal stromal cell subpopulations with distinct lineage commitment. PLoS One. 2012; 7(12): 1-12. doi: 10.1371/journal. pone.0051221

2. Soleimani M, Nadri S. A protocol for isolation and culture of mesenchymal stem cells from mouse bone marrow. Nature Protocols. 2009; 4(1): 102-106. doi: 10.1038/ nprot.2008.221

3. Al-Qaisy B, Yaseen N, Alwachi S, AL-Shammari A. Comparison between three different protocols for isolation and culture of mouse bone marrow derived mesenchymal stem cells. Iraqi J Cancer Med Genet. 2014; 7(1): 26-35.

4. Nadri S, Soleimani M, Hosseni RH, Massumi M, Atashi A, Izadpanah R. An efficient method for isolation of murine bone marrow mesenchymal stem cells. Int. J. Dev. Biol. 2007; 51: 723-729. doi: 10.1387/ijdb.072352ns

5. Caplan A. Mesenchymal stem cells: Time to change the name. Stem Cells Transl Med. 2017; 1-7. https://doi. org/10.1002/sctm.17-0051 
6. Schachtele S, Clouser C, Aho J. Markers and methods to verify mesenchymal stem cell identity, potency, and quality. https://www.cellandgene.com/doc/markers-and-methods-to-verify-mesenchymal-stem-cell-identity-potency-and-quality-0001

7. Oikonomopoulos A, Deen W, Manansala A, Lacey P, Tomakili T, Ziman A, Hommes D. Optimization of human mesenchymal stem cell manufacturing: the effects of animal/xeno-free media. Sci Rep. 2015; 5: 1-11. doi: 10.1038/ $\underline{\text { srep } 16570}$

8. Sung JH, Yang HM, Park JB, Choi GS, Joh JW, Kwon CH, Chun JM, Lee SK, Kim SJ. Isolation and characterization of mouse mesenchymal stem cells. Transpl Proc. 2008; 40: 2649-2654. doi: 10.1016/j.transproceed.2008.08.009

9. Hu Y, Lou B, Wu X, Wu R, Wang H, Gao L, Pi J, Xu Y. Comparative study on in vitro culture of mouse bone marrow mesenchymal stem cells. Stem Cells Intern. 2018; 1-14. doi: $10.1155 / 2018 / 6704583$

10. Peister A, Mellad J, Larson B, Hall B, Gibson L, Prockop D. Adult stem cells from bone marrow (MSCs) isolated from different strains of inbred mice vary in surface epitopes, rates of proliferation, and differentiation potential. Blood. 2004; 103(5): 1662-1668. doi: 10.1182/blood-2003-09-3070

11. Ikebe C, Suzuki K. Mesenchymal stem cells for regenerative therapy: optimization of cell preparation protocols. BioMed Research International. 2014; 1-11. doi: $10.1155 / 2014 / 951512$

12. Chaudhary JK, Rath PC. A simple method for isolation, propagation, characterization, and differentiation of adult mouse bone marrow-derived multipotent mesenchymal stem cells. J Cell Sci Ther. 2017; 8(1): 1-10. doi: 10.4172/2157$\underline{7013.1000261}$

13. Guide for the care and use of laboratory animals, Eighth Edition, 2011, National Academy of Sciences, 246 pages.

14. Roderfeld M, Rath T, Voswinckel R, Dierkes C, Dietrich H, Zahner D, Graf J, Roeb E. Bone marrow transplantation demonstrates medullar origin of CD34+ fibrocytes and ameliorates hepatic fibrosis in Abcb4_/_mice. Hepatology. 2010; 51:267-276. doi: 10.1002/hep.23274

15. Tohidi F, Toosi M, Azimian H, Khademi S, Fardid R, Sar$\mathrm{ab}$ GH. The gene expression level of p53 and p21 in mouse brain exposed to radiofrequency field. Int J Radiat Res. 2015; 13(4): 337-343. doi: 10.7508/ijrr.2015.04.007

16. Sibov Y, Severino P, Marti LC, Pavon LF, Oliveira DM, Tobo PR, Campos AH, Paes AT, Amaro E, Gamarra LF, Moreira-Filho CA. Mesenchymal stem cells from umbilical cord blood: parameters for isolation, characterization and adipogenic differentiation. Cytotechnology. 2012; 64: 511521. doi: 10.1007/s10616-012-9428-3

17. Castro-Silva I, Castro L, Machado J, Nicola M, Granjeiro J. Isolation of human umbilical cord blood-derived osteoprogenitor cells: a promising candidate for cell-based therapy for bone repair. Einstein. 2011; 9: 449-455. doi: 10.1590/ $\underline{\text { s1679-45082011ao2196 }}$
18. Baustian C, Hanley S, Ceredig R. Isolation, selection and culture methods to enhance clonogenicity of mouse bone marrow derived mesenchymal stromal cell precursors. Stem Cell Res Ther. 2015; 6(151): 1-13. doi: 10.1186/s13287-015$\underline{0139-5}$

19. Zhu H, Guo Z, Jiang X, Li H, Wang X, Yao H, et al. A protocol for isolation and culture of mesenchymal stem cells from mouse compact bone. Nature Protoc. 2010; 5(3): 550560. doi: $10.1038 /$ nprot.2009.238

20. Hasoon MF, Nader B, Mohammed MH. A study of the bone marrow derived mesenchymal stromal cells in rats proliferation and immunophynotypic markers. Malaysian J Vet Res. 2018; 9(1): 73-80.

21. Abdullah RH, Yaseen NY, Saleh SM, Mohamed MH, Al-Shammari A. Direct and simple method for mesenchymal stem cells isolation, culturing and detection. Int J Stem Cell Res. 2018; 5(2): 1-5. doi: 10.23937/2469-570X/1410054

22. Tropel Ph, Noel D, Platet N, Legrand P, Benabid A, Berger F. Isolation and characterisation of mesenchymal stem cells from adult mouse bone marrow. Exp Cell Res. 2004; 295: 395-406. doi: 10.1016/j.yexcr.2003.12.030

23. Fafián-Labora J, Fernández-Pernas P, Fuentes I, De Toro J, Oreiro N, Sangiao-Alvarellos S, Mateos J, Arufe MC. Influence of age on rat bone marrow mesenchymal stem cells potential. Sci Rep. 2015; 5: 1-20. doi: 10.1038/srep16765

24. Wang X, Yang J, Chen X, Pan X. Establishment and characterization of a fibroblast-like cell line from Anabarilius grahami (Cypriniformes: Cyprinidae). Dongwuxue Yanjiu. 2012; 33(E5-6): E89-E97. doi: 10.3724/SP.J.1141.2012.E05$\underline{06 \mathrm{E} 89}$

25. Madaan A, Verma R, Singh AT, Jain SK, Jaggi M. A stepwise procedure for isolation of murine bone marrow and generation of dendritic cells. Journal of Biological Methods. 2014; 1(e1): 1-6. doi: 10.14440/jbm.2014.12

26. Huang S, Xu L, Sun Y, Wu T, Wang K, Li G. An improved protocol for isolation and culture of mesenchymal stem cells from mouse bone marrow. J Orthop Transl. 2015; 3(1): 2633. doi: 10.1016/j.jot.2014.07.005

27. Augello A, Kurth TB, Bari CD. Mesenchymal stem cells: a perspective from in vitro cultures to in vivo migration and niches. Eur Cell Mater. 2010; 20: 121-133. doi:10.22203/ecm. v020a11

28. Jiang T, Xu G, Wang Q, Yang L, Zheng L, Zhao J, Zhang $\mathrm{X}$. In vitro expansion impaired the stemness of early passage mesenchymal stem cells for treatment of cartilage defects. Cell Death Dis. 2017; 8:1-12. doi: 10.1038/cddis.2017.215

29. Chen J, Sotome S, Wang J, Orii H, Uemura T, Shinomiya $\mathrm{K}$. Correlation of in vivo bone formation capability and in vitro differentiation of human bone marrow stromal cells. J Med Dent Sci. 2005; 52(1): 27-34. PMID: 15868738 


\section{Оптимизированный протокол выделения и культивирования мышиных мезенхимальных стромальных клеток}

Дима Джуджех ${ }^{1}$, Абдулджалил Гревати ${ }^{1},{\text { Чади Суккариех }{ }^{2}, \text { Аднан Альмаррави }^{1} \text {, Джамал А.Н. Дарвича }}^{3}$

${ }^{1}$ Департамент биотехнологической инженерии, Факультет технической инженерии, Университет Алеппо, Сирия

2 Департамент биологии животных, Факультет наук, Университет Дамаска, Сирия

${ }^{3}$ Департамент фармакологии и токсикологии, Факультет фармации, Арабский международный университет, Сирия

\section{Резюме}

Мезенхимные стволовые клетки (МСК) вызвали большой интерес в научном сообществе. МСК мышей служат идеальной моделью для изучения клеточной биологии и терапевтического потенциала этой популяции клеток. Поэтому необходимо создание оптимального стандартизованного протокола для выделения и культивирования мышиных МСК. Нашей целью было разработать и описать эффективный, надежный и простой в выполнении протокол для выделения и культивирования мезенхимальных стромальных клеток костного мозга мышей (МСКМ). Наш протокол основан на сочетании метода промывки и механического дробления костей. МСКМ, выделенные с использованием нашего протокола, имеют веретенообразную форму, проявляется экспрессия маркеров CD73 и CD44, слабая экспрессия CD34 и CD105 и отсутствие CD11b.
Эти клетки также способны дифференцироваться в другие ростки мезодермы, такие как клоны адипоцитов и остеоцитов. Мы надеемся, что данные, представленные в этой статье, имеют практическое значение и могут быть использованы в клинических и исследовательских приложениях, а также при заготовке клеток для банкирования.

\section{Ключевые слова}

Мыши Balb/c, костный мозг, изоляция клеток, мезенхимные стволовые клетки, первичная культура. 